\title{
Türkiye’de Kamu Politikası Olarak 2000 Yılı Sonrası Uluslararası Göç Yönetiminin Analizi
}

Yasemin MAMUR IŞIKÇI ${ }^{1}$

\begin{abstract}
Özet
Türkiye Cumhuriyeti kurulmasından itibaren pek çok göç akımına maruz kalmıştır. Nitekim özellikle 2000'li yıllardan itibaren de Avrupa Birliği'ne uyum süreci ile birlikte, Türkiye, göçle ilgili kurumsallaşma süreci, düzensiz göçe karşı alınan önlemler, göç ve mülteci rejimi, gibi konular bakımından önemli ölçüde Avrupa Birliği mevzuatına uyumlu politika izlemeye başlamıştır. Bu bağlamda, bu çalışmada 2000 yılı sonrasında Türkiye'de göç yönetimi ile ilgili olarak izlenen kamu politikalarının analizi yapılmaktadır. Analize konu olan sürenin belirlenmesinde AB (Avrupa Birliği) ile ilk Katılım Ortaklığı Belgesi'nin bu tarihte imzalanması ve bu çerçevede Türkiye'nin göç politikaları konusunda $\mathrm{AB}$ ile uyum içinde olmak zorunda kalacağı beklentisi rol oynamıștır. Analiz yapılırken Sabatier (2007)'in kullandığı süreç modeli esas alınmıştır. Süreç modeli, çeşitli aktörlerin etkileşimi ile farklı karar yöntemlerinin kullanılması sonucu ortaya çıkan kamu politikasının karmaşık yapısının anlaşılmasını kolaylaştırdığı için tercih edilmiştir. Yasalaşma sürecinde rol oynayan aktörleri açıklayabilmek için süreç modelinin yanına politika ağları yaklaşımı da katılmıştır.
\end{abstract}

Anahtar Kelimeler: Göç, Göç Yönetimi, Kamu Politikası Analizi, Türkiye

\section{Analysis of International Migration Management after 2000 as Public Policy in Turkey}

\begin{abstract}
Since its establishment, Republic of Turkey has been exposed to many waves of immigration. Hence with the European Union harmonization process since the 2000s, Turkey has pursued a set of policies such as the process of institutionalization of immigration, measures taken against irregular immigration, and refugees and immigration regime, which comply with the legislation of the European Union. In this context, this study provides an analysis of the public policies pursued in Turkey in terms of immigration management since the year 2000. The reasons for the selection of this period for analysis are that Turkey signed the first accession partnership document with the EU (European Union) in this year, and thus there has been an expectation that Turkey will be required to harmonize its process of allowing immigrants with that of the EU. Sabatier's (2007) process model was used for analysis as it facilitates an understanding of the complex structure of public policies arising from the interaction of several actors and the use of different methods of decision making. Due to the fact that the process model cannot satisfactorily explain the actors in the process of enactment, the policy networks approach was additionally used.
\end{abstract}

Key Words: Migration, Migration Management, Public Policy Analysis, Turkey

\section{Giriş}

Bireylerin ya da grupların yaşamlarının geri kalanını devam ettirmek üzere yer değiştirmeleri olarak tanımlanabilecek olan göç, eski zamanlardan beri bütün toplumları ilgilendiren bir olgu olarak varlığını ve önemini hala korumaktadır. Dahası, 20. yüzyılın ikinci yarısından itibaren, göç sorununun küreselleşme sürecine bağlı olarak, uluslararası olma yönünde nitelik değiştirmesi ve bu sürece çeşitli uluslararası sorunların da eşlik etmesi söz konusu olmuştur. Nitekim bütün

\footnotetext{
${ }^{1}$ Yrd. Doç. Dr. Giresun Üniversitesi, İ̈BF, Siyaset Bilimi ve Kamu Yönetimi Bölümü., mamurysm@gmail.com
} 
Yalova Sosyal Bilimler Dergisi

coğrafyaları etkileyen bir küresel göç krizi kapıdadır ve bu krizi yönetmek, en fazla da "göç alan" durumunda olan ülkeler için önem taşıyan bir süreçtir.

Çeşitli sebeplere bağlı olarak, yaşamlarını sürdürmek için, değişik şekillerde yer değiștirmek zorunda kalan insanlar, uluslararası belgelerin ve kurumların tanımlamalarında mültteci, sı̆̆ınmacı ve göçmen şeklinde sınıflandırmaya tabii tutulmuşlardır. 1951 sayılı Mültecilerin Hukuki Statüsüne İlişkin Cenevre Sözleşmesine göre mülteci, "lrkl, dini, tabiiyeti, belli bir toplumsal gruba mensubiyeti veya siyasi düşünceleri yüzünden, zulme uğrayacağından hakl sebeplerle korktuğu için vatandaşı olduğu ülkenin dışında bulunan ve bu ülkenin korumasindan yararlanamayan ya da söz konusu korku nedeniyle, yararlanmak istemeyen, yahut tabiiyeti yoksa ve bu tür olaylar sonucu önceden yaşadiğ ikamet ülkesinin dışında bulunan, oraya dönemeyen veya söz konusu korku nedeniyle dönmek istemeyen şahislar" (BM Cenevre Sözleşmesi, 1951) olarak tanımlanmıştır.

1951 tarihli Mültecilerin Hukuki Durumuna Dair Birleşmiş Milletler Cenevre Sözleşmesi'ne ${ }^{2}$ göre, sığınmacı "Vatandaşı olduğu devletin ülkesinde meydana gelen olaylar sonucunda ve $\mathrm{rkk}$, dini, tabiiyeti, belli bir toplumsal gruba mensubiyeti veya siyasi düşünceleri yüzünden, zulme uğrayacağından hakl sebeplerle korktuğu için vatandaşı olduğu ülkenin dışında bulunan ve bu ülkenin korumasından yararlanamayan, ya da söz konusu korku nedeniyle, yararlanmak istemeyen yahut tabiiyeti yoksa ve bu tür olaylar sonucu önceden yaşadı̆̆ ikamet ülkesinin dişında bulunan, oraya dönemeyen veya söz konusu korku nedeniyle dönmek istemeyen her şahıs" (BM Cenevre Sözleşmesi, 1951) olarak kabul edilmektedir. Çiçekli (2013: 129)'nin ifadesi ile mülteci ve sığınmacı arasında ki temel fark; mülteci'nin hukuken tanınmış bir statüye sahip olan yabancı, sığınmacının ise, mültecilik statüsü incelenen ancak yine de kendisine geçici koruma sağlanmış kişi olmasıdır.

Göçmen terimi ise, "kişisel rahatlık" amacıyla ve dışarıdan herhangi bir zorlama unsuru olmaksızın hür iradesiyle göç etmeye karar veren kişileri ifade etmektedir (Göç Terimleri Sözlügü: Göçmen). Günümüzde yaşanmakta olan insani krizi tanımlama konusunda yukarıda farklıl1kları belirtilen kavramlar, literatürde birbirinin yerine ya da birlikte kullanılır hale gelmiştir.

Türkiye Cumhuriyeti kurulduğu tarihten beri farklı zamanlarda ve farklı şekillerdeki uluslararası göç hareketleri ile karşı karşıya gelmiştir. Ne var ki, 1920'li yılların başında ulus-devlet inşa politikasının bir unsuru olarak Türk ve Müslüman kimlikli yabancı ülke vatandaşlarının Türkiye'ye göç etmesini bir yana koyarsak, Türkiye'ye yönelen yabancıların uluslararası göçü olarak

228 Temmuz 1951 tarihinde imzalan1951 tarihli Cenevre Sözleşmesi’ni Türkiye 29 Ağustos 1961 tarihinde onaylamıştır.4 Ekim 1967 tarihinde imzalanan Protokolü ise, Türkiye, 1 Temmuz 1968 tarihinde onaylamıştır. Sözleşmenin onaylanmasına dair 359 sayılı onay Kanununun Kabul tarihi: RG 05.10.1961/10898. Nitekim, Türkiye 1951 Cenevre Sözleşmesi’ni imzalarken, yine Sözleşmenin 42. maddesinin taraf devletlere verdiği kısıtlayıcı kayıt beyan etme hakkını kullanarak sadece Avrupa'dan gelen kişilere mülteci statüsü tanıyacağını belirtmiştir (Özer, 2011; Çelik, 2015). 
Yalova Sosyal Bilimler Dergisi

nitelendirilebilecek bir nüfus hareketinin 1980'li yıllara kadar sınırlı kaldığını söylemek mümkündür. Ancak 1980'lerle beraber, komşu ülkelerdeki savaşların da etkisiyle Türkiye'ye kitlesel ve düzensiz göç hareketleri yaşanmaya başlanmış ve bu süreçte Türkiye uluslararası göç bakımından çoğunlukla transit alan haline gelmiştir (İçduygu, Sert ve Karaçay, 2009'dan akt. Güleç, 2015: 92).

Önemli göç rotaları üzerinde yer aldığı ve tarih boyunca değişik amaçlarla yapılan göçlere ev sahipliği yapmak zorunda kaldığı için Türkiye açısından bu konu gittikçe önem kazanmaktadır. 20. yüzyılın ikinci yarısından itibaren göç sorununun küreselleşme ile nitelik değiştirmesi ve bu sürece çeşitli uluslararası sorunların da eşlik etmesi Türkiye'nin bu konuda kapsamlı bir kamu politikası izleme zorunluluğunu doğurmuştur.

Oysaki coğrafi konumu açısından göç kavşağında olan Türkiye, 2000'li yıllara gelinceye kadar bu konuda etkin bir politika izleyememiştir. Nitekim yabancıların ülkeye girişi, çıkışı, ülkede kalış süreleri, sınır dışı edilmeleri, vize ve ikamet izni, Türkiye'de sahip oldukları hak ve yükümlülükler gibi mevzular bu zamana gelinceye kadar 1950 tarihli ve 5683 sayılı Yabancıların Türkiye'de İkamet ve Seyahatleri Hakkında Kanun ve 5682 sayılı Pasaport Kanunu ile düzenlenmiştir. Ancak, 2000 sonrası uluslararası alanda ve dış politikada meydana gelen gelişmeler, Türkiye'yi uluslararası koruma alanında daha kapsamlı ve etkin düzenlemeler yapmaya zorlamıştır.

Türkiye'de son dönemde yaşanan söz konusu göç hareketleri güvenlik sorunları, işgücü piyasalarında dengelerin bozulması, kamusal hizmetlerin yetersiz kalması ve toplumsal gerilimlerin ortaya çıkması gibi olumsuz sonuçlara neden olabilecek niteliktedir. Bu nedenle, Türkiye'de son birkaç yılda her ne kadar bu süreci yönetmek için oldukça kapsamlı ve çok boyutlu düzenlemeler yapılmışsa da eksik kalan yönlerin de ortaya konulması gerekir. Bu yöndeki bir amaç, ancak öncelikle ilgili alanda yapılanlar ve yapılmayanlar gözler önüne serildikten sonra gerçekleştirilebilir. $\mathrm{Bu}$ da, kamu otoritelerinin bir alanda yapmayı ya da yapmamayı tercih ettiği her şey (Dye, 1995) diye ifade edilen kamu politikasının analizi anlamına gelmektedir. Bu bağlamda, bu çalışmada 2000 yılı sonrasında Türkiye'de göç yönetimi ile ilgili olarak izlenen kamu politikalarının analizi yapılmaktadır. Analize konu olan sürenin belirlenmesinde $\mathrm{AB}$ ile ilk Katılım Ortaklığı Belgesi'nin bu tarihte imzalanması ve bu çerçevede Türkiye'nin göç kabul etme konusunda AB ile uyum içinde olmak zorunda kalacağ oynamıştır. Analiz yapılırken Sabatier (2007)'in kullandığı süreç modeli esas alınmıştır. Süreç modeli, çeşitli aktörlerin etkileşimi ile farklı karar yöntemlerinin kullanılması sonucu ortaya çıkan kamu politikasının karmaşık yapısının anlaşılmasını kolaylaştırdığ analizi, politikanın oluşturulması (problemin tanımlanması, gündeme getirilmesi, politikanın kabulü), politikanın uygulanması ve politikanın değerlendirilmesi aşamalarını kapsamaktadır.

Bu modele göre kamu politikası analizi, gündeme geliş (sorunların tespiti), formüle ediliş, kanunlaştırma, uygulama, değerlendirme aşamalarından oluşmaktadır. Göçün ve beraberinde getirdiği sorunların zamanla sınırları aşan bir boyuta 
Yalova Sosyal Bilimler Dergisi

ulaşması göç yönetiminde küresel ve ulusal düzeyde işbirliğini zorunlu kılmaktadır. Dolayısıyla göç yönetimi ile ilgili kararların alınmasında birçok aktörün rol oynayacağ 1 açıktır. Bu nedenle göç yönetimi ile ilgili kararların nasıl alındığını ve nasıl uygulandığını açıklarken bu süreçlerde kimin ne şekilde payının da olduğunun ortaya konulması gerekir. Sorunun bu kısmına da çalışmada politika ağları modeli ile yaklaşılmaktadır.

$\mathrm{Bu}$ yöntemlerin kullanılması ile çalışmada şu soruların yanıtı aranmıştır; (1) Türkiye'de göç yönetiminin değişmesine neden olan problem/problemler nedir? $\mathrm{Bu}$ problem/problemler kim tarafından ne şekilde ifade edilmiştir? (2) Türkiye'de göç yönetimi nasıl ve hangi aktörlerin katkısı ile şekillendirilmiştir? (3) Türkiye'de göç yönetimi konusunda karar verilen politikaların uygulamaya geçirilmesi nasıl ve hangi aktörlerin katkıları ile gerçekleştirilmiştir? (4) Hâlihazırda uygulamaya konulmuş politikalar ne şekilde etkili olmaktadır ve hangi yönlerden eksiklikleri mevcuttur? Çalışmada, konu ile ilgili bilimsel ve teknik yayınlar, resmi internet siteleri, Resmi Gazete, Avrupa Birliği İlerleme Raporları, hükümet programları ve gazetelerin taranması yolu ile elde edilen veriler kullanılmıştır.

Literatür tarandığında konuya bu yöntemle yaklaşan bir çalışmaya rastlanmamıştır. Dolayısıyla bu çalışmanın hâlihazırda uygulanmakta olan göç politikasının hangi aşamalardan geçerek ve hangi aktörlerin katkısı ile oluştuğunu açık bir şekilde ortaya koyması açısından ayrılacağı umulmaktadır. Bununla birlikte; çalışmanın konusu ile doğrudan ilgili bazı araştırmalara rastlanmıştır. Bunları şu şekilde sıralayabiliriz; Güleç (2015), çalışmasında, AB göç politikalarındaki değişimin Türkiye'ye etkisini incelemiştir. Kara ve Dönmez Kara (2016) göç yönetiminin yönetişim boyutunu Türkiye'nin sürece uyumu açısından incelemişlerdir. Aliu, Öztürk, Aliu ve Özkan (2016) Türkiye'de göç olgusunu mevzuat ve bilimsel projeler çerçevesinde incelemişlerdir. Kolukırık (2014) Türkiye'de sığınmacı haklarının yerel uygulamalarını irdelemiştir. Özer (2011) çalışmasında uluslararası göç sorununu haklı olarak kamu yönetimi açısından yeni bir çalışma alanı olarak değerlendirmiş ne var ki konuyu ağırlıklı olarak yasalaşma süreci açısından ele alarak kararların alınmasında ve uygulanmasında etki eden aktörlerle yeterince ilgilenmemiş ve süreç hakkında bir değerlendirme yapmamıştır. Örselli ve Babahanoğlu (2016)'nun yaptıkları çalışmada da göç yönetimi, bir kamu politikası aracı olarak değerlendirilmiş ancak model ile ilgili yeterli açıklamalar yapılmadığı ve modelin gerektirdiği yöntemin izlenmediği, dolayısıyla çalışmanın kurumsal ve mevzuat analizi ile sınırlı kaldığı görülmüştür. Bu son iki çalışma bu çalışmanın konusu ve yöntemi ile en fazla ilgili olan araştırmalardır.

Bundan sonra kamu politikası kısaca tanımlandıktan sonra Sabatier (2007)'in kullandığı süreç modeli ve politik ağlar yaklaşımına göre Türkiye'de göç yönetimi politikasının nasıl ve kimler tarafından şekillendirilip uygulamaya geçirildiği açıklanacak en son kısımda politikanın güçlü ve zayıf yönleri değerlendirilecektir.

\section{Kamu Politikası Analizinde Süreç ve Politika Ağları Yaklaşımları}

Jean-Claude Thoenig kamu politikalarını bir veya birden çok kamu otoritesinin eylem programı olarak tanımlar. (Politiste, 2012'den akt. Usta, 2013: 81) 
Yalova Sosyal Bilimler Dergisi

Heywood, (2012: 54)'da benzer şekilde kamu politikasını hükümet kuruluşlarının resmi veya açıklanmış kararları olarak ifade etmektedir. Eyestone (1971: 18)'de kamu politikasının, hükümete ait bir birimin çevresi ile olan etkileşimi olduğunu söylemektedir. Kamu politikası Anderson (2006)'un tanımıla da bir sorunu çözmeye yönelik olarak, ilgili taraflar (aktörler) tarafından izlenen amaçlı hareket tarzıdır. Kamu politikası analizi merkezinde devlet örgütünün bulunduğu kamu politikası sürecini incelemeyi amaçlar (Bayırbağ, 2013: 44).

Kamu Politikasında süreç modeli kamu politikaları aşamalarında çeşitli aşamaların olduğunu varsaymaktadır. Süreç modeli herhangi bir politikanın uygulanmasına yol açan nedenlerin problem veya ihtiyaç olarak belirlenmesi, problemin çözümü veya ihtiyacın giderilmesi için gerekli formüllerin oluşturulması, formüle edilmesi ve kanunlaştırılması, bir sonraki aşamada kanunlaşan politikanın uygulanması ve son aşamada da politikanın etkinliğinin değerlendirilmesi aşamalarını (Sabatier, 1999) açıklamaktadır.

Politika ağı terimi kamu politikalarını şekillendiren aktörlerin etkileşim durumunu ifade etmektedir. Politika ağlarının üyeleri belirli bir toplumsal sorunu çözmek amaciyla bir araya gelerek çözümler üretirler. Sonra da bu çözümleri uygularlar. Söz konusu bu süreçte grup üyelerinin çıkarları, uygulanacak politikanın yönünü ve şeklini belirler. Ağ teoreminde ağ içindeki bir kurumun, ağın oluşturduğu kamu politikasını hangi yönde ve nasıl etkileyerek katkıda bulunduğu ve kamu yararını ne kadar gözettiği sorularına yanıt aranır ve böylelikle kamu politikalarının oluşma süreci bilimsel olarak açıklanabilir (Klijn ve Koppenjan, 2000). Bu çalışmada da göç yönetimi ile ilgili kararların nasıl alındığını ve nasıl uygulandığı bu süreçlerde kimin ne şekilde payının olduğu politika ağları yaklaşımı ile ortaya konulmaya çalışılmaktadır.

\section{Türkiye'de 2000 Yılı Sonrası Uluslararası Göç Yönetimi Çalışmalarının Süreç Modeli ve Politika Ağları Yaklaşımı İle Analiz Edilmesi}

Günümüz dünyasında kamu politikası, siyasi iktidarlara, birçok politik alanda yüz yüze geldikleri sorunları gidermeye yönelik kararlar almada değişik bilim dallarından gelen verilerle beslenen, bilimsel bilgilere dayalı ve rasyonel bir yol haritası sunar. İç ve dış politikanın en önemli konularından biri olan göç olgusu da küreselleşmenin neden olduğu faktörlerin de etkisi ile eskiye nazaran nitelik değiştirmiş ve daha problemli bir hal almıştır.

Nitekim Castles ve Miller (2008: 14)' de, ekonomik değişime, siyasal mücadelelere ve çatışmalara bağlı olarak tarihin eski dönemlerinden beri süregelen göç olgusunun hızının artması, etki sahasının genişlemesi, çeşitlenmesi ve giderek siyasallaşması yönünde form değiştirdiğinden bahsetmektedirler. Göç konusunda yaşanan bu değişmelerin beraberinde aynı ölçüde farklılaşmış ve büyümüş sorun yumağını da getirdiği muhakkaktır. Bu nedenle sorun çözmeye odaklanmış olan kamu politikalarının göç alanında gerekliliği açıkça ortadadır. Çalışmamız açısından cevaplanması gereken soru ise Türkiye'de göç ile ilgili kamu politikası nasıl oluşturulmuştur ve ihtiyacı karşılayabilmiş midir? Bu sorunun yanıtı da Sabatier (2007)'in kullandığı süreç modeli ve politik ağlar yaklaşımına göre 
Yalova Sosyal Bilimler Dergisi

aranacaktır. Söz konusu model gündeme geliş, formüle ediş, kanunlaştırma, uygulama ve değerlendirme aşamalarından oluşmaktadır.

Pek tabii ki Geçici koruma statüsü ile Türkiye'de uluslararası koruma altına alınan göçmenlere yönelik temel kamu hizmetlerinin sağlanması, toplumsal bütünleşme sürecinin yürütülmesi, çalışma imkanı verilmesi gibi sorunlar Türkiye'nin göç yönetimi alanında geniş kapsamlı, çok aktörlü ve etkin bir kamu politikası izlemesi gereğini doğurmuştur. Aktörlerin bu konudaki katkısı ise politika ağları yaklaşımı ile değerlendirilmiştir.

\subsection{Gündeme Gelme Aşaması}

$\mathrm{Bu}$ aşama, kamu politikalarının konusunu oluşturan sorunların somut bir şekilde belirlenerek çözülmesi için hükümetin önüne koyulmasını ifade etmektedir. Bu aşamada, politika ağları yaklaşımı çerçevesinde problemin kim tarafından hangi amaçlarla gündeme getirildiği, bunlar arasında karşıllklı etkileşim, işbirliği ve kaynak dağılımının olup olmadığ kadar olduğu gibi temel soruların yanıtlanması, sürecin daha detaylı bir şekilde ortaya konulabilmesi açısından önem arz etmektedir. Ancak bu analizi yapmadan önce göç politikalarında meydana gelen dönüşümün daha iyi açıklanması için, Türkiye'de büyük göç akımlarının geçmiş̧ine de değinmek yerinde olacaktır. Nitekim Türkiye Cumhuriyeti kurulmasından itibaren pek çok göç akımına maruz kalmıştır. Bunlardan, Cumhuriyetin kurulmasının ilk yıllarına rastlayan birinci dalga göç akımında, ulus - devlet yapılanmasını sağlamak amacıyla, Türkiye ile Yunanistan arasında nüfus mübadelesi edilmiş, böylece Türk ve Müslüman kökenli kişilerin ülke topraklarına girişi sağlanmıştır (İçduygu, 2010: 33). 1980'li yılların sonuna doğru ve 1990'lı yılların başından itibaren de Türkiye, önce Irak, Bulgaristan ve Yugoslavya, daha sonra ise tekrar Irak'tan gelen göç dalgalarının etkisi içine girmiştir (İçduygu \& Yükseker, 2012: 452'den akt. Bayındır Goularas \& Sunata, 2015: 20). Türkiye son y1llarda ise çok çeşitli ülkelerden göç almaya devam etmektedir.

1990'l1 yıllardan itibaren komşu ülkelerde yaşanan iç karışıklıklar ve savaşlar Türkiye'yi göç olgusu açısından sığınma ülkesi ve özellikle transit ülke olarak öne çıkarmışıır ${ }^{3}$ Nitekim Türkiye bu tür göçmenler tarafından kendileri için daha iyi yaşam koşullarını temsil eden Avrupa'ya giden bir köprü olarak görülmektedir. Pek çok insanın, baskı, şiddet, çatışmalar ve yoksulluk sebebi ile Avrupa'ya doğru hareket etmesi üye ülkelerin kısıtlayıcı göç politikalarını uygulamaya koymalarına neden olmuştur. Bu politikalar ise yasadışı göçü artırırken göçmenleri de sınır aşan organize suç türlerinin mağdurları haline getirmektedir. Böylece Türkiye, küreselleşme ile nitelik değiştiren, büyüyen ve karmaşıklaşan göç olgusunun

\footnotetext{
${ }^{3}$ Kara ve Korkut (2010:157)'un aktardığına göre, ülkeye gelen ilk kitlesel mülteci grubu 1979 İran Devrimi'nin ardından olmuştur. 1980-1991 yılları arasında Türkiye üzerinden Kuzey Avrupa ülkeleri ve Avrupa'ya 1,5 milyon İranlı'nın göç ettiği tahmin edilmektedir.

İkinci büyük grubu 1988-1991 tarihleri arasında İran-Irak Savaşı, Saddam Hüseyin'in Halepçe'de giriştiği katliam ve Körfez Savaşı neticesinde ülkelerinden kaçan 600 bin Iraklı Kürt oluşturmaktadır. Bu insanların büyük kısmı da Batı'ya hareket etmişlerdir (Mannaert, 2003'den akt. Kara \&Korkut,2010:158).
} 
Yalova Sosyal Bilimler Dergisi

beraberinde getirdiği, yasa dışı göç, insan ticareti ve insan kaçakçılığı gibi, ülkelerin güvenliğini tehlikeye düşüren sorunların merkezi olarak görülmeye başlanmıştır. Avrupa Birliği de kendi üye devletlerinin güvenliklerini sağlayabilmek için transit ülke durumunda olan Türkiye'den güçlü bir göç kontrol sistemi kurmasını ve böylelikle Türkiye'den AB'ne doğru gerçekleşecek düzensiz göç hareketlerinin engellenmesini istemektedir.

Öte yandan, 11 Eylül saldırısından sonra Avrupa güvenliği için en önemli tehdit göç kaynaklı suçlar olarak görülmüş ve $\mathrm{AB}$ içinde, sınırların güvenliği, yasadışı göç, insan kaçakçılı̆̆ı, dolandırıcılık ve örgütlü suçlarla mücadele konularında işbirliği yönünde kararlar alınmıştır (Özcan, 2005:4'den akt. Kolukırık, 2014: 4243). Bu kapsamda AB Türkiye ile ortaklık antlaşması imzalarken Türkiye'nin göç kontrol sistemini oluşturmasını şart koşmuştur. $\mathrm{Bu}$ şekilde $\mathrm{AB}$, Türkiye ile imzalanan uluslararası anlaşmalar ve Avrupa Birliği’ne uyum süreci kapsamında, günümüz göç politikalarını şekillendiren önemli unsurlardan biri olarak ön plana çıkmaktadır. Nitekim özellikle 2000'li yıllardan itibaren Avrupa Birliği'ne uyum süreci ile birlikte, Türkiye'nin göçle ilgili kurumsallaşma süreci, düzensiz göçe karşı alınan önlemler, göç ve mülteci rejimi, gibi konular bakımından önemli ölçüde Avrupa Birliği mevzuatına uyumlu bir gelişme kaydettiği görülmektedir. AB Düzenli İlerleme Raporlarında da bazı eksikliklerin vurgulanmasına rağmen bu gelişme memnuniyetle ifade edilmektedir .

Türkiye'ye yönelik uluslararası göç açısından önemli bir unsur olan yasa dışı göçmenler sadece Avrupa'nın güvenliği açısından değil, Türkiye'nin toplumsal, siyasi ve ekonomik yapısı açısından da büyük bir sorun teşkil etmektedir. Nitekim, Avrupa'ya geçmek amacıyla çeşitli ülkelerden Türkiye'ye gelen yasadışı göçmenlerin pek çoğu, Türkiye'nin, taraf olduğu Mültecilerin Hukuki Durumuna İlişkin 1951 Cenevre Sözleşmesi’nde mülteci tanımını, "1 0cak 1951 tarihinden önce Avrupa'da yaşanan olaylar nedeni ile iltica edenlerle" sınırlı tutması yüzünden Türkiye'de sıkışıp kalmaktadırlar. Türkiye'ye gelen göçmenlerin pek çoğu Avrupalı olmadığı için Türkiye'nin mülteci tanımlamasının dışında kalmakta ama diğer yandan da zulüm görecekleri yerlere de gönderilememektedirler. Sayıları her geçen gün artan bu kişiler, sığınma taleplerini kabul eden ülke bulamamaları halinde Türkiye'de yasadışı olarak yaşamayı tercih etmektedirler (Özer, 2011: 75). Böylece Türkiye yasadışı göçmen cenneti bir ülkeye dönüşmektedir.

Türkiye'nin göç politikalarının gelişimine etki eden başka bir unsur da 2011 yılından bu yana Suriye'de yaşanan iç savaş nedeniyle fazla miktarda sığınmacı akımına uğramasıdır. Nitekim Göç İdaresi Genel Müdürlüğü’nün verilerine göre Türkiye'de 2012 y1lında 14237 olan geçici koruma kapsamındaki Suriyeli sı ğınmacıların sayısı yıllar içinde artarak Haziran 2017 tarihi itibari ile 3.069.963 civarına ulaşmıştır. Bunların dışında 70.000 civarında düzensiz göç kapsamında ülkeye yasa dışı giriş yapan Suriyeli vatandaşlar mevcuttur. Bu sayının Suriye'deki savaşın devam etmesi durumunda daha da artacağı ön görülmektedir. Nisan 2012

${ }^{4} 2015$ yılı İlerleme Raporu'na göre Türkiye, göç ve iltica alanındaki olağan dışı sınamalarla mücadele etmek için büyük ölçüde seferber olmuştur Türkiye'nin göç ve uluslararası koruma ile belge güvenliği alanlarında kaydettiği ilerleme memnuniyetle karşılanmıştır. 
Yalova Sosyal Bilimler Dergisi

tarihinden itibaren İçişleri Bakanlığ 1994 Yönetmeliği'ne ${ }^{5}$ dayanılarak Suriyeli vatandaşlara geçici koruma statüsü tanınmıştır. Böylelikle Türkiye Cumhuriyeti devleti temel kamu hizmetlerini sağlama yükümlülüğü altına girmiştir. Pek tabii ki geçici koruma statüsü ile, Türkiye'de uluslararası koruma altına alınan bu göçmenlere yönelik temel kamu hizmetlerinin sağlanması, toplumsal bütünleşme sürecinin yürütülmesi, çalışma imkanı verilmesi gibi sorunlar Türkiye'nin göç yönetimi alanında geniş kapsamlı, çok aktörlü ve etkin bir kamu politikası izlemesi gereğini açıkça ortaya koymuştur.

\subsection{Formülasyon Aşaması}

Türkiye'de 2013 yılına gelene kadar uluslararası göç hareketleri çok sayıda ve çeşitli mevzuatta dağınık bir şekilde düzenlenmiştir. Uluslararası koruma dişında kalan yabancılara ilişkin iş ve işlemleri düzenleyen 1950 tarihli 5682 sayı1lı Pasaport Kanunu ile Yabanciların Türkiye'de İkamet ve Seyahatleri Hakkında Kanun bunların en önemlileridir. Ancak bu kanunlar da, güncel gelişmelerle birlikte gelen sorunları çözecek kadar kapsamlı değildirler. Türkiye'de göçmenler, sığınmacılar ve mültecilerle ilgili konuları düzenleyen en kapsamlı yasa 2006 yılında 5543 sayılı yasa ile yenilenen 1934 sayılı İskân Kanunu'dur. Ne var ki bu yasa da soydaş odaklı bir çerçeve çizdiği için mevcut göç akımları ile ilgili sorunlar karşısında yetersiz kalmıştır (Örselli \& Babahanoğlu, 2016: 2066).

Türkiye'de göç sorununu düzenleyen mevzuatlardaki dağınıklık kurumsallaşma konusunda da çok başlilığa ve düzensizliğe yol açmıştır. Nitekim, bu zamana gelene kadar, ülkeye giriş yapan yasadış1 göçmenlerin kontrol altına alınması, ikamet edecekleri merkezlere yerleştirilmesi, gerektiğinde sınır dışı edilmesi gibi konularla İçişleri Bakanlığı'na bağlı Emniyet Genel Müdürlüğü'nün Yabancılar Şubesi ve Valilikler birlikte faaliyet göstermişlerdir. Bu nedenle AB müktesebatına uyum kapsamında göç yönetimi için kurumsal bir yapılanmanın gerekliliği özellikle vurgulanmış ve idari kapasitelerinin geliştirilmesine yönelik çalışmalar ve talepler dile getirilmiştir (Demirhan \& Aslan, 2015: 46).

$\mathrm{Bu}$ kapsamda göç alanında izlenmesi gereken temel stratejileri belirleyen bir çok doküman yayınlanmıştır. Bunlardan birisi olan 2003 tarihli Katılım Ortaklığ 1 Belgesinde "yasadışı göç" ile mücadelenin güçlendirilmesine devam edilmesi ve Avrupa Komisyonu ile bir geri kabul anlaşmasının müzakere edilmesi, orta vadede ise "yasadışı göçü" önlemek amacıyla göçe ilişkin $A B$ müktesebatının ve uygulamalarının kabul edilip yürürlüğe koyulması ve sığınma alanında uyum sağlanması, 1951 Cenevre Sözleşmesine getirilen coğrafi kısıtlamanın kaldırılması ile ilgili çalışmalara başlanması, sığınma başvurularının değerlendirilmesi ve kararlaştırılması sisteminin güçlendirilmesi, sığınmacılar ve mülteciler için konaklama birimleri ve sosyal destek sağlanması amaçlanmıştır. Bu yaklaşım 2003 Ulusal Programına aynı şekilde yansımıştır (ORSAM, 2012: 20).

\footnotetext{
${ }^{5}$ Adı geçen yönetmeliğin tam adı Türkiye’ye İltica Eden veya Başka Bir Ülkeye İltica Etmek Üzere Türkiye'den İkamet İzni Talep Eden Münferit Yabancilar ile Topluca Siğınma Amaciyla Sinırlarımıza Gelen Yabancılara ve Olabilecek Nüfus Hareketlerine Uygulanacak Usul ve Esaslar Hakkında Yönetmelik, Kabul Tarihi : 14.09.1994 R.Gazete Tarihi : 30.11.1994, R.Gazete No : 22127
} 
Yalova Sosyal Bilimler Dergisi

Sonra ki süreçte 2003 tarihli Avrupa Birliği Müktesebatının Üstlenilmesine İlişkin Türkiye Ulusal Programı doğrultusunda hazırlanan İltica ve Göç Ulusal Eylem Planı 25 Mart 2005 tarihinde hazırlanmıştır. Bu plan ile, Türkiye'nin AB'ne katılım müzakereleri sürecinde Türk İltica, Göçmen ve Yabancılar Mevzuatının ve Sisteminin AB müktesebatı ve sistemleri ile uyumlu hale getirilmesi amaçlanmıştır. Plan, Türkiye'nin iltica ve göç mevzuatı ve sisteminin $\mathrm{AB}$ müktesebatı ile uyumlu hale getirilmesi için, uyumlaştırma sürecinde yürürlüğe konması gereken yasal düzenlemeleri, idari yapılanma ve fiziki alt yapının tamamlanması için gereken yatırımları ve alınması gereken önlemleri kapsamaktadır. Bu kapsamda Planda;

(1) Göç ve iltica alanında bir ihtisas biriminin oluşturulması, oluşturulacak yapının içerik yönünden güçlendirilmesi, (2) İltica ve göç alanında çalışacak personelin istihdamı ve eğitiminin sağlanması, (3) İltica ve göç alanında yeni yatırım ve eşleştirme projelerinin gerçekleştirilmesi, (4) Menşe ülke ve iltica bilgi sisteminin tesis edilmesi, (5) Kabul ve barınma merkezleri ile geri gönderme merkezlerinin tesis edilmesi, (6) Gelecekte nüfus hareketlerini etkileyecek ekonomik, sosyal ve politik değişimler göz önünde tutularak iltica ve göç politikalarının gözden geçirilmesi gibi hedefler öngörülmüştür.

2008 yılında yayınlanan Ulusal Programda da, Türkiye'nin İltica ve Göç Ulusal Eylem Planı'nın uygulanması konusunda bir yol haritasının kabul edilmesini de içeren çabaların devam ettirilmesi, $\mathrm{AB}$ müktesebatı ile uyumlu bir iltica otoritesinin kurulmasını da içeren kapsamlı bir iltica kanunun kabulü için hazırlıkların yapılması ve yasadışı göçle mücadele konusunda uluslararası standartlarla uyum içerisinde kapasitenin artırılması şeklinde daha önce belirlenen hedefler tekrarlanmıştır (ORSAM, 2012: 21).

Ne var ki, Ulusal Eylem Planı'nın ön gördüğü kurumsallaşma ve yasal düzenleme konusunda uzunca bir süre adım atılmamıştır. Türkiye, 2011 yılından sonra Suriye'de yaşanan iç savaş nedeniyle büyük boyutlu sığınmacı akımına uğrayıp da büyük bir krizle karşı karşıya kalınca daha önce alınmış olan bu kararların uygulamaya geçirilmesi mümkün olabilmiştir. 64. Hükümet programında yer alan şu ifadeler bundan sonra göç yönetimi konusunda atılacak olan adımların $A B$ merkezli ve öncelikli olacağını ve bu konuda kararlı bir tutum izleneceğini haber vermektedir.

"Son dönemlerde Suriye'de yaşanan iç çatışmaların etkisiyle artan mülteci akını, bölge ülkelerini aşarak başta $\mathrm{AB}$ olmak üzere uluslararası ölçekte bir meseleye dönüşmüştür. $\mathrm{Bu}$ alanda $\mathrm{AB}$ ile Türkiye diyalogu ve işbirliğinin önemi giderek artmaktadır. $A B$ ile sürdürdüğümüz ilişkiler bütünlüğü içinde bu alanda da yeni inisiyatifler geliştirilmesi önem arz etmektedir Cumhurbaşkanımız Sayın Recep Tayyip Erdoğan, 2014 yılını AB yılı ilan ederek bu süreçteki kararlılığı bir kez daha gözler önüne sermiştir. Bu çerçevede, $\mathrm{AB}$ sürecine yeni bir ivme kazandırmak ve her alanda reform çalışmalarını hızlandırmak amacıyla hazırlanan AB'ye Katılım İçin Ulusal Eylem Planı'nı titizlikle hayata geçireceğiz." 
Yalova Sosyal Bilimler Dergisi

\subsection{Kanunlaştırma Aşaması}

Avrupa Birliği'nin göç yönetimi konusunda Türkiye'den istediği en önemli konuların başında göçmen kaçakçıllğı ve insan ticareti sorunları gelmektedir. Bir ülkeye yasadışı yollardan girişi ifade eden göçmen kaçakçılığına karşı BM Sınıraşan Örgütlü Suçlarla Mücadele Sözleşmesi (Palermo) Türkiye tarafindan 2000 yılında imzalanmış ve bu sözleşmeyle birlikte Göçmen Kaçakçılığına Karşı Ek Protokol ile İnsan Ticaretine Karşı Ek Protokol 2003 yılında onaylanmıştır. Bunlara ek olarak, 2002 yılında TCK'nin 79. Maddesinde yapılan değişiklikle insan ticareti suçuna ilişkin ön görülen cezalar da artırılmıştır.

Göç alanında yapılan düzenlemelerin büyük bir kısmının hareket noktası Suriyeli sığınmacıların yasal haklarını ve hukuki durumlarını açıklığa kavuşturma amacı olmuştur. Bilindiği gibi, Türkiye'ye gelişlerinin ilk zamanlarında Suriyelilere, uluslararası hukukta bir karşılığı olmayan misafir statüsü verilmiştir (Güneş, 2014: 6). Sonraki aşamada ise Suriyelilere, Nisan 2012 tarihinden itibaren İçişleri Bakanlığı 1994 Yönetmeliği'ne dayanarak dünyanın farklı coğrafyalarında yaşanan benzer krizler sonrası oluşturulan "geçici koruma statüsü" tanınmıştır. Bu rejim, asgari uluslararası standartların ön gördügüu, açık kap1 politikası, geri dönmeye zorlamama, bireysel statü belirlemenin yapılmaması, kamplarda barınma ve diğer temel hizmetlerin sunumu gibi ilkeleri kapsamaktadır (Ihlamur \& Öner, 2014: 44'den akt. Güneş, 2014: 6) .

Krizin büyümesi ve Suriyeli göçmenlerin sayısının giderek artması üzerine 2005 Yılı İltica Göç Ulusal Eylem Planı'nda çıkarılması öngörülmüş olan 6458 sayılı Yabancilar ve Uluslararas1 Koruma Kanunu TBMM Genel Kurulunda kabul edildikten sonra 11.04.2013 tarihli ve 28615 sayılı Resmi Gazetede yayımlanarak yürürlüğe girmiştir. 6458 sayılı Kanun' un 91. maddesinde 'Ülkesinden ayrılmaya zorlanmış, ayrıldığ 1 ülkeye geri dönemeyen, acil ve geçici koruma bulmak amacıyla kitlesel olarak sınırlarımıza gelen veya sınırlarımızı geçen yabancılara geçici koruma sağlanabilir" ifadesi ile geçici korumanın kapsamı açıklanmıştır. Daha sonra Kanun' un bu hükmüne dayanılarak çıkarılan 13 Ekim 2014 tarihli ve 2014/6883 say1lı Geçici Koruma Yönetmeliği Türkiye'de geçici koruma rejimine yönelik esas düzenlemeyi oluşturmuştur (Güneş, 2014: 7-8).

Ulusal Eylem Planı kapsamında hedeflenen birçok husus, 6458 sayılı Yabancılar ve Uluslararası Koruma Kanunu ile, mevzuat ölçeğinde somutlaştırılmıştır. Beş kısım ve 126 maddeden oluşan Yabancılar ve Uluslararası Koruma Kanunu, geri gönderme yasağı, yabancıların durumları, uluslararası koruma, yabancılar ve uluslararası korumaya ilişkin ortak hükümler ile Göç İdaresinin kuruluş ve işleyişine ilişkin hükümler içermektedir (Ergüven \& Özturanl1, 2013: 1032'den akt. Parlak \& Şahin, 2015: 72).

Göç yönetimi alanında yapılan en büyük düzenlemelerden biri de, 16 Aralık 2013 tarihinde, Türkiye ile Avrupa Birliği Arasında İzinsiz İkamet Eden Kişilerin Geri Kabulüne İlişkin Anlaşma ve Vize Serbestisi Diyalogu Mutabakat Metni imzalanmasıdır. Türkiye-Avrupa Birliği Geri Kabul Anlaşması, Türkiye'de veya AB'ye üye ülkelerden birinde, ülkeye giriş, ülkede bulunma veya ikamet etme 
Yalova Sosyal Bilimler Dergisi

koşullarını sağlamayan veya sağlayamaz duruma düşen kişilerin, anlaşmada belirlenen şartlar ve kurallar çerçevesinde ilgili ülkeye geri gönderilmesi, buna karşılık, Türk vatandaşlarına $\mathrm{AB}$ içinde vize muafiyeti tanınması için diyalog sürecinin başlatılması unsurlarını içermekteydi. Anlaşma imzalanmadan önce 4 Aralık 2013'de yaptığı bir açıklamada, dönemin başbakanı Davutoğlu Vize muafiyeti tanınmasının Gümrük Birliği'nden bu yana bütün Türk halkının beklentisi olduğunu vurgulamış, vize diyalogunun ilk toplantısının 16 Aralık tarihinde Ankara'da gerçekleştirileceğini ve buna paralel olarak da geri kabul anlaşmasının imzalanacağını, böylece Türk vatandaşlarının en geç üç buçuk yıl zarfında $\mathrm{AB}$ için tam vize muafiyeti imkânına kavuşacağını belirtmiştir. İlave olarak da işbirliği ruhuyla belirlenen zaman çizelgesi sona ermeden de vize muafiyetinin hayata geçirilebileceğini düşündüğünü ve alınan kararın Türkiye'nin Avrupa ailesinin parçası olduğu gerçeğini bir defa daha ortaya koyduğunu ifade etmiştir (Dış İşleri Bakanlığı, 2017). Bu ifadeler; Türkiye'nin, Avrupa'ya yönelen düzensiz göç sorununu yıllardan beri isteyip de gerçekleştiremediği vize muafiyeti kazanımını elde etmek için firsat olarak kullandığını ortaya koymaktadır. Bu anlamda o dönem için Avrupa'nın önceliği, kendi ülkelerine yönelmiş düzensiz göçe karşı önlem almak, Türkiye'nin önceliği ise vize muafiyeti sağlamaktır. Bu anlamda düzensiz göç, daha çok Avrupa'nın sorunudur demek bu noktada pek de yanlış olmayacaktır. AB her ne pahasına olursa olsun bu sorunu kendi toprakları dışında önlemek istemektedir.

$\mathrm{Bu}$ nedenle, yukarıdaki anlaşmaya ek olarak $\mathrm{AB}$ ve Türkiye arasında, 15 Ekim 2015 tarihinde, Türk iye üzerinden AB'ye yönelen düzensiz göçü kontrol altına almak için Ortak Eylem Planı üzerinde anlaşma yapılmıştır (Avrupa Komisyonu, AB-Türkiye Ortak Eylem Planı: Bilgi Notu).Türkiye, bu plan çerçevesinde, kendi topraklarından Avrupa'ya yönelen düzensiz göç hareketlerini engellemeye yönelik çabalarını arttırmayı ve Türkiye'den geçerek Avrupa'ya ulaşan ve AB üye devletlerince uluslararası korumaya ihtiyaç duymadığı değerlendirilen düzensiz göçmenlerin kendine geri gönderilmesini kabul etmekte; $\mathrm{AB}$ de, bunların karşılığında Türkiye'de yaşayan Suriyelilerin ihtiyaçlarının karşılanması için Türkiye'ye 3 milyar Avro tutarında (yaklaşık 3,4 milyar ABD Doları) yardımda bulunmayı taahhüt etmektedir.

Ancak takip eden süreçte, Avrupa'ya doğru gerçekleşen düzensiz göçlerde istenen düzeyde azalma olmaması üzerine taraflar, 18 Mart 2016 tarihinde, ikinci bir anlaşma üzerinde mutabakata varmışlardır (Avrupa Birliği Konseyi, AB-Türkiye Anlaşması). Söz konusu anlaşma uyarınca 20 Mart 2016 tarihi itibariyle Türkiye'den yola çıkarak Yunanistan adalarına ulaşan tüm düzensiz göçmenler Türkiye'ye geri gönderilecektir. $A B$ ise karş1lık olarak, toplam 72 bin mülteciyi aşmamak kaydıyla, Yunanistan'dan Türkiye'ye gönderilen her bir Suriyeli mülteci için Türkiye'de yaşayan bir Suriyeli mültecinin AB'ye yerleştirilmesi, Türkiye Mülteci Aracı adı altında 6 milyar avroluk bir fonun (yaklaşık 6,7 milyar ABD Doları) Türkiye'ye tahsis edilmesi, Türkiye vatandaşlarına Haziran 2016 itibariyle vize serbestisinin tanınması ve Türkiye'nin hâlihazırda yavaşlamış olan AB üyeliği için yürütülen müzakere sürecinin canlandırılması taahhütlerinde bulunmuştur (Uluslararas1 Af Örgütü, 2016: 4-5). 
Yalova Sosyal Bilimler Dergisi

Böylelikle, $\mathrm{AB}$ göç denetimini, Avrupa'nın sınırlarının dışında yapılmasını amaçlamaktadır. Ancak, bu amacını tamamen gerçekleştirmesini engelleyen coğrafi çekincenin Türkiye tarafindan kaldırılmasını istemektedir. Coğrafi çekinceye göre Türkiye, taraf olduğu Mültecilerin Hukuki Durumuna İlişkin 1951 Cenevre Sözleşmesi’nde mülteci tanımını "1 0cak 1951 tarihinden önce Avrupa'da yaşanan olaylar nedeni ile iltica edenlerle" sınırlı tutmuştur. Çekincenin kaldırılması ile birlikte, Avrupa'ya sığınmacı girişi engellenirken, birçok alanda mültecilere kendi vatandaşlarına tanıdığı hakları tanımak zorunda kalacağı için Türkiye'nin de mülteciler konusundaki ekonomik ve siyasi sorumlulukları da artacaktır (Güner, 2007'den akt. Bayındır Goularas \& Sunata: 2015: 27). Diğer yandan, çekincenin kaldırılmaması nedeni ile, Türkiye'de mülteci olamayan göçmenler, yasal veya yasadışı yollardan $\mathrm{AB}$ ülkelerine geçmenin yollarını aramaktadırlar. $\mathrm{Bu}$ durum ise insan ticareti ve göçmen kaçakçılı̆̆ konusunda Türkiye'yi odak noktası haline getirmektedir. Coğrafi çekince, Türkiye'nin ek protokolü imzalamasından itibaren uluslararası kamuoyunun dikkatini çekmiş ve özellikle son yıllarda Uluslararası Af Örgütü gibi pek çok sayıda sivil toplum kuruluşunun eleştiri konusu haline gelmiştir (Bayındır Goularas \& Sunata: 2015: 29).

Uluslararas1 Af Örgütü, “Dünyanın en zengin siyasi bloğu olan Avrupa Birliği uzun yıllardır yaşanan ... yerinden edilme krizi karşısında sığınmacı ve mültecilerin Avrupa'ya erişimini etkili bir biçimde engellemeye çalışıyor. AB, Kale Avrupası olarak adlandırılan politikalar çerçevesinde kara sınırlarına tel örgüler çekiyor, giderek artan sayıda sınır muhafizını konuşlandırıyor, komşusu olan ülkelerle göçmen ve mültecileri dışarıda tutmak için anlaşmalar imzallyor" ifadeleri ile Avrupa Birliği’nin göçmenlere yönelik uyguladığı politikaları eleştirirken, Türkiye'nin coğrafi sınırlamayı halen muhafaza eden tek Avrupa Konseyi üyesi olduğu gerçeğini de hatırlatmaktadır (Uluslararası Af Örgütü, 2016: 4-6).

\subsection{Uygulama Aşaması}

6458 Sayılı Yabancılar ve Uluslararası Koruma Kanunu'nun getirdiği önemli yeniliklerden biri yabancılara ilişkin çalışma izni hariç tüm işlemleri yürüten polis yerine sivil bir otorite olan İçişleri Bakanlığı bünyesinde Göç İdaresi Genel Müdürlügü̈'nün kurulmasıdır ( Çelik, 2015: 73). Bu kanunla her ilde bir İl Göç İdaresi Müdürlüğü, 148 ilçede İlçe Göç İdaresi Müdürlükleri kurulması kararlaştırılmış; bununla birlikte 15 Göç Müşavirliği ve 85 Göç Ataşeliği oluşturulması yönünde de çalışmalar hızlandırılmıştır (Göç İdaresi Genel Müdürlüğ̈̈, 2017a).

Genel Müdürlük, göç alanına ilişkin politika ve stratejileri uygulamak, bu konularla ilgili kurum ve kuruluşlar arasında koordinasyonu sağlamak, yabancıların Türkiye'ye giriş ve Türkiye'de kalışları, Türkiye'den çıkışları ve sınır dışı edilmeleri, uluslararası koruma, geçici koruma ve insan ticareti mağdurlarının korunmasıyla ilgili iş ve işlemleri yürütmek üzere faaliyet göstermektedir (Göç İdaresi Genel Müdürlüğü, 2017a). Göç İdaresi Genel Müdürlüğü, görev ve sorumluluklarını yürütmek için merkez-taşra-yurt dışı şeklinde teşkilatlanarak kurulmuştur. Müdürlük bünyesinde, geri gönderme merkezleri, kabul ve barınma 
Yalova Sosyal Bilimler Dergisi

merkezleri ile insan ticareti mağdurlarının barınması için sığınma evleri açılarak göçmenlerin insani koşullarda muamele görmesi sağlanmaya çalışılmıştır.

6458 sayılı Kanun'un göç yönetimi konusunda kurulmasını ön gördüğü başka bir teşkilatlanma da Göç İdaresi Genel Müdürlüğü'ne bağlı olarak oluşturulan Göç Politikaları Kurulu'dur. Kanunda Kurulun, düzenli aralıklarla İç İşleri Bakanı'nın başkanlığında toplanması öngörülmüştür. Kanunun 105. Maddesine göre Kurul, İçişleri Bakanı'nın başkanlığında, Aile ve Sosyal Politikalar, Avrupa Birliği, Çalışma ve Sosyal Güvenlik, Dışişleri, İçişleri, Kültür ve Turizm, Maliye, Millî Eğitim, Sağlık ve Ulaştırma, Denizcilik ve Haberleşme bakanlıkları müsteşarları ile Yurtdışı Türkler ve Akraba Topluluklar Başkanı ve Göç İdaresi Genel Müdüründen oluşmaktadır. Ayrıca gündem konularına bağlı olarak ilgili Bakanlık, ulusal veya uluslararası diğer kurum ve kuruluşlar ile sivil toplum kuruluşlarının temsilcilerini de toplantıya davet edebilecektir. Kurul, Türkiye'nin göç politika ve stratejilerinin belirlenip uygulanmasının takibi, kitlesel akın durumlarında uygulanacak tedbirlerin belirlenmesi, toplu halde Türkiye'ye kabul edilen yabanciların ülkeye giriş ve kalışları ile ilgili hususların düzenlenmesi, yabancı işgücüne olan ihtiyacın belirlenmesi, uzun dönem ikamet iznine ilişkin şartların oluşturulması, göçle ilgili yabancı ülkeler ve uluslararası kuruluşlarla işbirliğinin artırılmasına yönelik uygulamaların ortaya konması, göçle ilgili çalışmalar yürüten kamu kurum ve kuruluşları arasında koordinasyon sağlanmasına yönelik kararların alınması görevlerini yürütmektedir (Göç İdaresi Genel Müdürlüğü, 2017b).

Merkezi düzeyde göç yönetiminde genel müdürlüğe bağlı ve belli aralıkla çalışmak üzere Göç Politikaları Kurulu'nun dışında başka kurul ve komisyonlar da Kanun'un 113. ve 117. maddeleri arasında düzenlenmiştirler. Kamu kurumları temsilcileri, öğretim elemanları ve gerektiğinde bu alanda faaliyet yürüten küresel kuruluşların temsilcilerinden oluşan bu komisyonlar Göç Danışma Kurulu, Uluslararas1 Koruma Değerlendirme Komisyonu ve Düzensiz Göçle Mücadele Koordinasyon Komisyonudur. Bunlardan Göç Danışma Kurulu'nun başlıca görevi, göç alanında yapılan politikaları izleme, bunlarla ilgili önerilerde bulunma, bu konuda yapılacak yeni politikalarla ilgili olarak değerlendirmede bulunmak, uluslararası ve bölgesel politikaları analiz ederek bunların Türkiye'ye yansımalarını incelemek, göç ile ilgili mevzuat çalışmaları ve uygulamalarını değerlendirmektir. Uluslararası Koruma Değerlendirme Komisyonu'nun temel görevi ise; göç yönetiminin yetkili birimlerine yapılmış uluslararası sığınma başvuruları üzerine verilen kararlarla (idari gözetim, kabul edilemez başvuru ve hızlandırılmış değerlendirme sonucu verilmiş kararlar hariç) ilgili itirazları değerlendirmek ve karara bağlamaktır. Kurul, ayrıca, uluslararası korumanın iptali ya da sona ermesine ilişkin olarak yapılan itirazları değerlendirerek karara varır. Son olarak, Düzensiz Göçle Mücadele Koordinasyon Kurulu da bu yapıda, düzensiz göç ile etkin mücadele edebilmek amacıyla ilgili kamu kurum ve kuruluşları arasında koordinasyonu sağlamak, yasa dışı biçimde Türkiye'ye yapılan giriş ve çıkış yollarını tespit ederek bununla ilgili önlemler geliştirmek, düzensiz göçle alakalı tedbirleri almak, bu alanda geliştirilip, uygulanacak mevzuat ile ilgili çalışmaları planlamak ve uygulamasını izlemekle görevlendirilmiştir (Göç İdaresi Genel Müdürlüŭü, 2017c). 
Yalova Sosyal Bilimler Dergisi

Göç Yönetimi alanında faaliyet gösteren başka bir aktör de 2009 yılında kabul edilen 5902 sayılı Kanun ile Başbakanlığa bağlı olarak kurulan Afet ve Acil Durum Yönetimi Başkanlığı (AFAD)'dır. 18.12.2014 tarih ve 34202324-010.06.0227767 say1lı Geçici Koruma Altındaki Yabancılara İlişkin Hizmetlerin Yürütülmesi başlıklı 2014/4 numaralı Başbakanlık genelgesine göre; geçici koruma altındaki yabancılara ilişkin hizmetlerin yürütülmesi AFAD koordinasyonunda ilgili diğer kurum ve kuruluşlar tarafından yerine getirilecektir. Ayrıca, geçici koruma altındaki yabancı sayısının on bini geçtiği illerde il müdürü başkanlığında olmak üzere oluşturulan komisyonlar, illerinde geçici koruma altındaki yabancıların sorumlu oldukları hizmet alanlarına ilişkin iş ve işlemleri AFAD koordinasyonu altında ilgili kurum ve kuruluşlarla işbirliği içerisinde yürüteceklerdir (Güneş, 2014: 9). AFAD söz konusu bu hizmetleri vermek üzere, Ocak 2017 verilerine göre 10 ilde 23 barınma merkezinde, 13 adet çadır kent ve 9 konteynır kentte, yaklaşık 260.000 Suriyeliye hizmet vermektedir (AFAD, 2017).

6458 sayılı Kanun ile yukarıda bahsedildiği üzere merkezi düzeyde göç yönetimini yürütmek üzere Göç İdaresi Genel Müdürlüğü ve bu müdürlüğe bağlı Göç Politikaları Kurulu sorumlu tutulmuşlardır. Bunlara yardımcı olmak üzere de yukarıda bahsi geçen kurul ve komisyonlar ile AFAD görevlendirilmişlerdir. Yerel düzeyde göç yönetimini ise valilerin sorumluluğunda Göç İdaresi Müdürlügüünün ve Afet İşleri Daire Başkanlığı'nın taşra birimleri olan Göç İdaresi ve Afet Acil Durum İl Müdürlükleri yürüteceklerdir. Yerel düzeyde Afet ve Acil Durum Müdürlükleri ise il düzeyinde çadır kent ve konteynır kentlerin yönetiminden sorumlu tutulmuş iken, Göç İdaresi İl Müdürlükleri de göç eden kişilerin kayıt altına alınması, istatistiklerinin tutulması, oturma izinleri, sınır dışı edilmeleri vb. faaliyetleri yürütmekle görevlendirilmişlerdir (Demirhan \& Aslan, 2015: 52). Böylece, daha önce İçişleri Bakanlığı'nın onayı ile yapılan işlemleri yürütme yetkisi Yabancılar ve Uluslararası Koruma Kanunu ile Göç İdaresi Genel Müdürlügü̈'nün taşra teşkilatına bırakılmıştır. Bu durum, Şeker ve arkadaşlarının (2014) belirttikleri gibi göç yönetimi ile ilgili işletilen karar alma süreçlerinde taşra örgütünün aktör olarak tanımlaması sonucunu doğurmuştur.

6458 say1lı kanun yerel yönetimlere göç yönetimi ile ilgili olarak doğrudan görev vermemiştir. Bununla birlikte; hâlihazırda özellikle belediyeler kendi kanunlarına dayanarak göçmenlere yönelik sosyal yardımlarda bulunmaktadır (Demirhan \& Aslan, 2015: 52-54). Ancak, son dönemlerde Türkiye'nin kamu yönetimi yapısında, yerelin merkez karşısında güçlendirilmesi ve yönetişimci kurumların yaygınlaştırılması yönünde önemli bir dönüşüm yaşandığı gerçeğinden yola çıkılarak gelecekte yapılacak düzenlemelerle yerel yönetimlerin de göç ile ilgili karar alma süreçlerine katılması beklenebilir. Dolayısıyla, yerel yönetimlerin, özellikle de belediyelerin önümüzdeki süreçte yerel düzeydeki göç yönetiminde mevcut yapılanmanın yanında üçüncü bir aktör olarak yer alacağı değerlendirmesinde bulunmak çok da zor olmayacaktır.

\subsection{Değerlendirme Aşaması}

Bir politikanın değerlendirilmesi, alanda yapılıp edilenlerin eksiklik ve başarılarının ortaya konulmasını gerektirir. Bir anlamda değerlendirme aşamasında, 
Yalova Sosyal Bilimler Dergisi

belirli bir alanda izlenilen politikanın, sorunun hangi yönlerine katkı sağladığı ve hangi yönlerini eksik bıraktığı belirlenir. $\mathrm{Bu}$ anlamda konusu Türkiye'nin uluslararası göç yönetimi olan politikanın değerlendirilmesi için de, belirli soruların yanıtı aranmalıdır. Bunlar; göç yönetimi konusunda gerçekleştirilen yasalaşma süreci hukuksal açığı kapatabilmiş midir? Bu kapsamda kurulan kurumlar ihtiyaçları karşılayabilmiş midir? İzlenen politika kimleri nasıl etkilemiştir? Hangi sorunları çözmüştür? Nerelerde eksiklik kalmıştır? Şeklinde siralanabilir.

Türkiye, sıklıkla hem münferit, hem de kitlesel göç akımlarına maruz kalan bir ülke durumunda olmakla birlikte iltica ve göç konularını içeren kapsamlı bir hukuki mevzuata uzunca bir süre sahip olamamıştır. Bu nedenle göçlerle birlikte gelen kimi sorunların giderilememesi Türkiye'yi insan hakları açısından uluslararası alanda zor duruma sokmuştur ${ }^{6}$. Bu sıkıntıları gidermek için her ne kadar 1994 yılında 6169 sayılı İltica Yönetmeliği yürürlüğe konulmuşsa da yönetmelikte mülteci kavramının sadece Avrupa'da meydana gelen olaylar nedeniyle sı̆̆ınan yabancılarla sınırlı tutulması göç ve iltica olaylarının sebep olduğu hukuki problemleri çözememişti. Bu gibi nedenler dolayısıyla 11 Nisan 2013 tarihinde 6458 sayılı Yabancilar ve Uluslararası Koruma Kanunu'nun Resmi Gazete'de yayınlanarak yürürlüğe girmesi, ülkede bulunan göçmenlerin hukuki statülerini açıklığa kavuşturması açısından olumlu bir adım olmuştur. Her ne kadar bu kanunda da Cenevre Sözleşmesi ve 1994 tarihli İltica yönetmeliğinde olduğu gibi, mültecilik statüsü sadece Avrupa Ülkelerinden gelenlerle sınırlandırılmış olsa da göçmenler için 'şartlı mülteci' ve 'ikincil koruma' şeklinde iki yeni statü tanımlaması daha yapılmış ve haklar sağlanmıştır. Buna göre Avrupa dışından gelen göçmenlere de 'şartlı mülteci' statüsü sağlanmakta ve diğer bir ülkeye yerleşene kadar Türkiye'de ikametlerine izin verilmektedir. Durumları bu iki statüye uymayanlar ise ikincil koruma yolu ile ülkede kalacaklardır. Kanunun 91. Maddesinde de ülkeye toplu olarak gelen sığınmacılar için 'geçici koruma' sağlanacağı özellikle ifade edilmiştir. Böylece sayıları gittikçe artan Suriyeli sığınmacıların hukuki statüleri daha açık bir şekilde ortaya konularak onlar için izlenecek politikaların dayanağı oluşturulmuştur.

Bundan önceki dönemde Suriyeli mültecilere hiçbir hukuki karşılığı olmayan misafir statüsü verilmişti. $\mathrm{Bu}$ tanımlama ise onların asgari olarak sağlanması gereken kamusal hizmetlerden bile hak sahibi olarak yararlanmalarını engellemekteydi. Nisan 2013 de çıkarılan kanunla birlikte bu sorunların çözümü adına 'Göç İdaresi Genel Müdürlüğ̈̈' kurulmuştur. Bünyesinde uzman personel çalıştıran, sadece göç yönetimi alanında faaliyet gösteren ve politika belirleyen, aynı zamanda sivil bir kurum olan Göç İdaresi Genel Müdürlügü’nün kurulması oldukça önemli bir adımdır. Bu gelişme ile, hizmetlerin bu zamana gelene kadar Emniyet Genel Müdürlüğü ve Valilikler tarafından yürütüldüğ̈ alanda bilgisizlik ve çok başl1lıktan kaynaklanan karmaşaya da son verilmiştir.

6 “Türkiye, 2009 Dünya Sığınmacı Raporunda sığınmacılara insani yaşam standartlarını sağlama açısından en kötü ülkeler arasında yer almıştır. ...Söz konusu raporda bunun yanı sıra şiddet ve kötü muamele de belirtilmiş ve Türkiye sınır dışı etme, fiziksel koruma ve mahkemelere ulaşım olanağı kategorilerinde not sıralamasındaki en kötü not olan F ile; hareket özgürlüğü ve iş olanakları kategorilerinde ise Dile değerlendirilmiştir” (Kartal \&Başçı 2014:287) 
Yalova Sosyal Bilimler Dergisi

Diğer yandan, geri gönderme merkezlerinin işletmesinin özel sektör tarafindan sağlanacağı Yabancilar ve Uluslararası Koruma Kanunu'nun 58. maddesinde düzenlenmiştir. Buna göre, bundan böyle göç yönetimi alanında sunulması gereken kamusal faaliyetler özel güvenlik birimleri eliyle sunulabilecektir. Ancak, bu durum, ülkelerinden edilmiş ve bu nedenle mağdur olmuş göçmenlerin geri gönderme sırasında tamamen devlet korumasından yoksun birakılması ve özel şirketler tarafından her türlü şekilde istismar edilmeleri sonucunu doğurabilecek bir uygulamadır. Nitekim Şeker ve arkadaşları da (2014: 123) söz konusu bu uygulamayı yapan Birleşik Krallık'ta yabancıların (kaçak göçmenler ve diğerleri) sınır dışı edilmeleri sırasında cinsel, fiziksel ve psikolojik taciz olaylarının sıklıkla yaşandığını aktarmaktadırlar.

Göç yönetimi konusunda faaliyet gösteren bir diğer kurum da AFAD'dır. Suriye'de yaşanan çatışmaların ilk zamanlarından bu yana kitleler halinde Türkiye'ye sığınanların bir kısmı geçici koruma kapsamında AFAD'ın kurduğu kamplarda yaşamaktadır. AFAD 2015 yılı içinde Suriyeli göçmenlere yönelik olarak 684.643.561,27 TL harcama yapmıștır. Bu oran AFAD'ın Afet ve Acil Durum Faaliyetleri Ödeneği kapsamında 2015 yılı içinde yaptı̆̆ 1 harcamaların \%98'ine denk gelmektedir (AFAD, 2015: 74). Bir habere göre Türkiye'nin Suriyelilere beş yılda yaptığı toplam harcamanın miktarı ise 8 milyar doları bulmaktadır. Uluslararası camianın bu orana katkısı ise sadece 450 milyon dolardır (Hürriyet, 28 Ocak, 2016). Bu oranın büyüklügü̈, Türkiye'nin Suriyeli sığınmacılar özelinde uluslararası göçü yönetmek için oldukça kararlı bir tutum sergilediğini ve bu konuda neredeyse yalnız bırakıldığını göstermektedir.

Bununla birlikte; politikanın konusu durumunda olan mülteciler için söz konusu olan ve çözülmesi gereken daha birçok problem mevcuttur. Her ne kadar göçmenlerin barınma sorununu çözmek için AFAD tarafından çok sayıda kamp kurulmuş olsa da Suriyelilerin \%90'1 kamp dışında yaşamaktadır. Kamp dışında yaşayan Suriyelilerin temel kamu hizmetlerine erişim ve istihdam konusunda ciddi sıkıntıları bulunmaktadır. Nitekim Suriyeli Mülteciler: 2013 Saha Araştırması Sonuçlarına göre ise kamp dışındaki Suriyeli mültecilerin yüzde 25'i harabelerde ya da derme çatma düzenlerde yaşamaktadır. Uluslararası AF Örgütü (2014) raporuna göre Suriyeliler ülke çapındaki kamu hastanelerinde ücretsiz muayene ve ücretsiz tedavi hakları mevcut, ancak sağlık hizmetlerine erişim kayıt olma esasına dayalı olduğu için kayıtlı olmayan Suriyeli mülteciler sağlı hizmetlerinden yararlanamamaktadır.

2016 Şubat'ta yayınlanan Başbakanlık Genelgesi ile Suriyeli göçmenlere çalışma hakkı verilmiş olmasına rağmen, 4817 Sayılı Yabancıların Çalışma İzinleri Hakkında Kanun işverene önemli mali yükümlülükler getirdiği için göçmenlerin çoğu yasadışı olarak kötü şartlar altında çalışmak zorunda kalmaktadırlar (Mazlumder, 2014; Emin, 2016: 12'den akt. ORSAM, 2014). Bu konuda Türk iş dünyası Türkiye'deki Suriyelilerin özellikle güney ve doğu bölgelerde tarımda ya da inşaat sektöründe kayıtsız ve yasa dışı bir şekilde çalıştırıldıklarını ifade ederken bu yöndeki istismarın giderilmesi için sektörel-bölgesel analizlerin yapılması 
Yalova Sosyal Bilimler Dergisi

gerektiğini vurgulamakta ve özellikle çalışma hakları konusundaki düzenlemelerin giderilmesi gerektiğine dikkat çekmektedir (Erdoğan ve Ünver, 2015: 78).

Eldeki verilere göre Türkiye'deki Suriyelilerin \%53'ünden fazlası 18 yaș altındaki çocuk ve gençlerden, oluşmaktadır (Kaya ve Yılmaz Eren,2014: 28; Kap, 2014: 31) (Bkz. Kap, 2014). Türkiye'ye gelen Suriyeli mültecilerin \% 53'ünün çocuk olduğu düşünüldüğünde, çocukların korunması da Suriye krizinde karşılaşılan en önemli konulardan biri olmaktadır. Bu konuda sıkça görülen sorunlar, çocuk/erken yaşta evlilikler, çocukların eğitime erişimleri, çocuk işçiliği, kapasite sıkıntıları, refakatsiz ve ailesinden ayrı düşmüş çocuklar ve doğum kaydıdır (Öztürk, 2015: 6). İnsan Hakları İzleme Örgütü'nün Kasım 2015 tarihli Türkiye' deki Suriyeli Mülteci Çocukların Eğitime Erişiminin Önündeki Engeller raporunda vurgulandığına göre, 2014-2015 y1lında 400 binden fazla Suriyeli çocuk okula gitmemektedir.

Diğer yandan, ECPAT International ile birlikte Uluslararası Çocuk Merkezi tarafindan hazırlanan, Çocuğa Karşı Ticari Cinsel Sömürü ile Mücadele Türkiye Durum Raporu (2015), Suriyeli mülteci çocukların zorla evlendirilme, fuhuşa zorlanması, üçüncü ya da dördüncü eş olarak satılma şeklinde cinsel sömürü amaçlı çocuk ticaretine maruz bırakıldığını ortaya koymaktadır. Suriyeli çocuklar için cinsel sömürü kadar ekonomik amaçlı sömürü de söz konusudur. Nitekim özellikle 6 yaşından 18 yaşına kadar pek çok Suriyeli çocuğun farklı iş kollarında ve sokaklarda uygunsuz koşullarda çalıştıkları farklı araştırmalarla ortaya konulmuştur (Bkz. Harunoğlulları, 2016).

Çocuklarla ilgili başka bir sorun da önemli bir kısmının refakatsiz ya da anne ve birini kaybetmiş durumda olmalarıdır. Söz konusu çocuklara hizmet vermek üzere Adana Sarıçam Geçici Barınma Merkezi içinde refakatsiz çocuklara özgü birim oluşturulmuştur. Suriye uyruklu refakatsiz çocuklara özgü birimlerin ihtiyaç duyulan diğer illere yaygınlaştırılmasına yönelik çalışmalar ile aile bakım modellerinden yararlandırılmasına yönelik proje çalışmaları devam etmektedir (ASPB, 2017).

Türkiye'nin izlemiş olduğu göç yönetimi ile ilgili en ciddi değerlendirmeler Uluslararası Af Örgütü'nden gelmektedir. Rapora yer alan ifadelere göre,

\begin{abstract}
....sıı̆ınma sistemi hâlâ kurulma aşamasında olan Türkiye yüz binlerce sı̆̆ınmacının yaptığı bireysel başvuruları da değerlendirme kapasitesinden yoksundur. Devlet kurumları, barınma başta olmak üzere, kişilerin temel ihtiyaçlarını karşılamamakta, kişilerin kendilerine yetebilmelerinin önünde de ciddi engeller bulunmaktadır. Bu haliyle Türkiye, sığınmacı ve mültecilerin onurlu bir yaşam sürdürebilecekleri bir ortamı tesis edememiş durumdadır Bu nedenle Türkiye'nin sığınmacı ve mülteciler geri kabul anlaşmalarının öngördüğ̈̈ güvenli bir ülke olduğu varsayımı bir kurgudan ibarettir. Dolayısıyla $\mathrm{AB}$, mevcut durum itibariyle sığınmacı ve mültecilerin haklarına tam olarak saygı gösterme kapasitesine sahip olmayan bir ülkeye geri gönderilmelerine umursamaz bir şekilde onay vermiştir. AB-Türkiye Anlaşması mülteciler bakımından kötü bir anlaşmadır; sığınmacı ve mültecilerin bu anlaşma çerçevesinde geri gönderilmeleri askıya alınmalıdır. (Uluslararası Af Örgütü, 2016).
\end{abstract}

Göç yönetimi konusunda halihazırda izlenen politikanın Suriyelilerin bütün problemlerini çözdügünü söylemek ne kadar güç ise, politikanın diğer bir unsuru 
Yalova Sosyal Bilimler Dergisi

olan Türk vatandaşlarının sığınmacı akını ile ilgili yaşadıkları sorunları giderdiğini söylemek de o derece zordur. Bu sorunların en başında da güvenlik konusu gelmektedir. Ağır ve Sezik (2015:107), Suriye'ye karşı uygulanan açık kapı politikası nedeniyle sınır güvenliğinin iyice zayıfladığından, böylece Suriye'de güç kazanan radikal unsurların, sızarak Türkiye'de terör eylemi gerçekleştirdiklerinden bahsetmektedirler. Nitekim yasadışı bir grubun 11 Şubat 2013 tarihinde Cilvegözü sınır kapısında, 11 Mayıs 2013 tarihinde de Reyhanlı'da gerçekleştirdikleri 50'den fazla kiş̧inin hayatını kaybettiği saldırıların sonraki tarihlerde de arkası gelmiştir. $\mathrm{Bu}$ durum, göçle birlikte gelen sınır güvenliği sorununun önemli bir iç tehdit meselesi haline geldiğini gözler önüne sermektedir (Ağır \& Sezik, 2015: 113,116). Benzer şekilde, Erdoğan ve Ünver (2015: 74)' de Türkiye'de cezaevlerinde bulunan yabancılar içinde Suriyelilerin sayısının \% 40'a ulaştığını belirtmekle birlikte, terör gruplarında faaliyet gösteren kişilerin de güvenlik sorunları yaratabileceklerine dikkat çekmektedirler.

Bununla birlikte, yerel halk arasında sığınmacılara yönelik var olan tepkinin bir provokasyon neticesinde şiddet içeren kitlesel tepkiye dönüşmesi sonucunda Suriyelilerin örgütlenerek kendilerini korumaya çalışması da söz konusudur. Son dönemde Suriyeliler arasında kendilerini korumak için ortak hareket etme ve örgütlenme konusu tartışılmaya başlanmıştır. Suriyelilerin örgütlenmesi ise iki toplumun giderek kutuplaşmasına neden olmaktadır (Orhan \& Gündoğar, 2015,19'dan akt. Ağır \& Sezik, 2015:117). Diğer yandan, yerel halkın Suriyelilerle birlikte iş firsatlarının ellerinden alındığ 1 ve bulundukları yerlerde kiraların artmasına neden oldukları gibi kanılar da Suriyelilere yönelik tepkileri artırmaktadır. Bu noktada siyasi iktidarın Suriyelilere, vatandaşlık verilmesi ve TOKİ konutlarının tahsis edilmesi yönündeki açıklamaları da yerel halk tarafından memnuniyetsizlikle karşılanmıştır (Bkz. Özer,2016; Aslan, 2016; Yazıcıŏlu, 2016, Giritli, 2016). Buna karşılık, Göç Araştırmaları Merkezi Başkanı Metin Çorabatır, tüm mülteciler için vatandaşlık başvurusu hakkı tanınması gerektiğini, böylelikle Türkiye'nin Suriyeli mültecileri kendi ulusal koruması altına alarak, kalıcı bir çözüm sağlamış olacağını savunmuştur (Karaca, 2016). Muhalefet ise bu konuda kendi ülkelerinde yaşanan sorunun bir an önce çözüme kavuşturulması için girişimlerde bulunmak yerine söz konusu ülke vatandaşlarına vatandaşl1k hakkı tanınmasının sorunlara yeni sorunların eklenmesinden başka bir anlam ifade etmeyeceğini savunmuştur (CHP, 2017).

Diğer bir gerilim de 24 Ağustos 2016 tarihinde Türk Silahlı Kuvvetlerinin Suriye'nin Halep kentine bağlı Cerablus bölgesine girişi ile başlayan Fırat Kalkanı harekâtından sonra bölgeden gelen şehit haberleri üzerine, Türk askerinin bölgede savaşmasına karşılık Suriyeli erkeklerin kendi ülkelerinin savunmasına katkı vermemesi konusunda başlamış bulunmaktadır. Bu rahatsızlık nedeniyle başlatılan ve oldukça da yankı bulan bir imza kampanyasında Suriyeli erkeklerin savaştan kaçmaları sonucu sivil halkın; çocuklar, kadınlar, yaşlılar, kronik hastalar ve engellilerin savunmasız kaldıkları ileri sürülürken Suriyeli erkeklerin, belli bir temel askeri eğitim aldıktan sonra, belli askeri operasyonlar ve harekâtlar kapsamında kendi vatanları için mücadeleye katılmalarının sağlanması gerektiği ifade edilmektedir (www.change.org). Bu söylem toplumun birçok kesimi tarafindan da destek görmeye başlamıştır. Bu anlamda önümüzdeki günlerde 
Yalova Sosyal Bilimler Dergisi

Suriyeli halk ile yerel halk arasında, özellikle askerlik ve vatandaşlık tartışmalarından kaynaklanan huzursuzluk ortamı nedeni ile çatışmaların yaşanması muhtemel görünmektedir. Bu bakımdan kamu yönetimi açısından bu gerilimlerin giderilmesi için nasıl bir çatışma ve kriz yönetimi izleneceği konusunda hazırlıklı olmak gerekmektedir.

\section{Sonuç}

Sayıları üç milyonu aşan Suriyeli sığınmacılarla ilgili hizmetleri sağlamak üzere 6458 Sayılı Kanun ile Göç İdaresi Genel Müdürlüğ̈ kurularak uzman bir yapılanmaya gidilmiştir. Buna ek olarak, bu alanda Başbakan Yardımcılığı, Başbakanlık Göç Koordinatörlüğü, İçişleri Bakanlığı, AFAD, Sağlık, Milli Eğitim, Çalışma ve Sosyal Güvenlik ve Aile ve Sosyal Politikalar Bakanlıkları, valilikler, kısmi olarak da yerel yönetimler ve kaymakamlıklar birlikte faaliyet göstermektedirler. Göç yönetimi konusunda hâlihazırda izlenen politikalara rağmen Suriyeli sığınmacıların kamusal hizmetlere erişimleri ile ilgili sıkıntıları ciddi ölçüde devam etmektedir. Bununla birlikte, ilerleyen dönemlerde yeni sığınmacı akımları, aile birleşimleri ve doğumlar nedeni ile ülkede bulunan sığınmacı sayısının daha da artması beklenmektedir. Dolayısıyla sığınmacılara verilen hizmetleri yönetme konusunda mevcut yapılanmanın yeterli olmayacağı açıktır. $\mathrm{Bu}$ nedenle Erdoğan ve Ünver (2015: 82)'in belirtikleri üzere bu konuda bakanlık düzeyinde bir yapılanmaya gitmek gerekmektedir.

Diğer yandan, ülkeye doğru yaşanan sığınmacı akımı Türk toplumunda, başta güvenlik ve istihdam kaygıları olmak üzere çeşitli sosyal ve ekonomik huzursuzluklara yol açmıştır. Siyasi iktidar tarafindan gelen Suriyelilere vatandaşlık açıklamaları da, Türk toplumunda eşitlik ve adalet değerleri bakımından bir tedirginliğe yol açmıştır. Oysaki toplumsal güvenliğin sağlanması açısından gerginliklerin azalması ve iki toplumun uyum içinde yaşamayı başarabilmesi gerekir. Bu anlamda, hem Suriyeli hem de Türk toplumuna bu konuda yardım edecek, yol gösterecek entegrasyon politikalarının katkısı büyük olacaktır. Bununla birlikte, bu konuda her iki toplum arasındaki denge gözetilmeden ve her iki toplumun da rızasına dayandırılmayan her türlü girişim, zaten bıçak sırtında olan gerilimi tırmandıracak ve iki kesimi de etkileyecek bir nefret söyleminin ortaya çıkmasına neden olacaktır. Bu açıdan öncelikle, son derece hassas bir konu olan entegrasyon süreci ile ilgili açıklamalar dikkatli ve detaylı bir şekilde yapılmalıdır. Buna ek olarak, sürecin gerçekleşmesi için atılması gereken adımların da titizlikle planlanması, uygulanması, sürecin her aşamasında her iki halkın da bilgilendirilmesi ve karşılıklı uzlaşının sağlanması gerekmektedir. Aksi uygulamaların kuşkusuz toplumsal barış için aksi yönde sonuçlar doğurması pek muhtemeldir.

Bu makalede 2000 yılı sonrasında Türkiye'de göç yönetimi ile ilgili olarak izlenen kamu politikalarının analizi yapılmıştır. Çalışmada Katılım Ortaklığı Belgesi’nin imzalanması ile, göç kabul etme konusunda $\mathrm{AB}$ ile uyum içinde olmak zorunda kalmasının Türkiye'nin göç yönetimi ile ilgili izlemiş olduğu politikaların temel nedeni olduğu, Suriye Savaşı ile artan sığınmacı akınının süreci hızlandırdığı kanısına varılmıştır. Türkiye'den de Avrupa'ya doğru yönelen sığınmacı tehdidini 
Yalova Sosyal Bilimler Dergisi

kendi toprakları dışında durdurmak isteyen $\mathrm{AB}$ ise, sürecin her aşamasında etkin bir rol izlemiştir. Aradaki ufak pürüzler bir yana $\mathrm{AB}$ ve Türkiye bugüne kadar bu konuda uyum içinde olmuşlardır.

\section{Kaynakça}

Ağır, O. \& Sezik, M. (2015). Suriye'den Türkiye’ye yaşanan göç dalgasından kaynaklanan güvenlik sorunlar1. Birey ve Toplum, 5(9),95-123.

Aliu, A. \&Öztürk, İ. \& Aliu, D. \& Özkan,Ö. (2016). Türkiye'de göç olgusunun mevzuat, politikalar ve bilimsel projeler çerçevesinde incelenmesi.2nd Internatıonal Congress on Applied Sciences:Migration, Poverty and Employment, 19-28.

Altmış Dördüncü Hükümet Programı. 2 Ocak 2017'de erişildi, http://www.basbakanlik.gov.tr/docs/KurumsalHaberler/64.hukumet_programi.pdf,

Anderson, J.(2006). Public policymaking. (6th.edt.),Houghton Mifflin Company, USA.

Aslan, R. (13 Temmuz 2016). Suriyelilere vatandaşlik: AKP seçmeni ne diyor? BBC Türkçe, 2 Ocak 2017'de erişildi, http://www.bbc.com/turkce/haberler-turkiye-36780544,

Avrupa Birliği Konseyi, AB-Türkiye Anlaşması, (4 Nisan 2016). 2 Ocak 2017'de erişildi, http://europa.eu/rapid/press-release_MEMO-16-1221_en.htm.)

Avrupa Birliğii Müktesebatının Üstlenilmesine İlișkin Türkiye Ulusal Programı. 2 Ocak 2017'de erişildi, http://www.ab.gov.tr/196.html

Avrupa Komisyonu, AB-Türkiye Ortak Eylem Planı: Bilgi Notu, (15 Ekim 2015). 2 Ocak 2017'de erişildi, http://europa.eu/rapid/press-release_MEMO-155860_en.htm

Başak, C. (2011), Mülteciler, Sığınmacılar ve Yasadışı Göçmenler, Ankara

Bayındır Goularas G. \& Sunata, U. (2015). Türk dış politikasında göç ve mülteci rejimi. Hacettepe Üniversitesi Illetişim Fakültesi Kültürel Çalışmaları Dergisi, 2(1): 12-40.

Bayırbağ, M.K.(2013) .Kamu politikası analizi için bir çerçeve. (Ed.Yıldız vd. ), Kamu Politikası Kuram ve Uygulama, Adres Yayınları.

BM Cenevre Sözleşmesi (1951). 2 Ocak 2017'de erişildi, http://www.goc.gov.tr/files/files/multec\%C4\%B1ler\%C4\%B1nhukuk\%C4\%B1statusune \%C4 $\% \mathrm{~B} 11 \% \mathrm{C} 4 \% \mathrm{~B} 1 \mathrm{sk} \% \mathrm{C} 4 \% \mathrm{~B} 1 \mathrm{nsozlesme.pdf}$

Castles, S. \& Miller M. J. (2008). The Age of Migration: (Turkish translation): Göçler Caği: Modern Dünyada Uluslarası Göç Hareketleri., İstanbul: Bilgi Üniversitesi.

CHP Resmi Web Sayfası. 2 Ocak 2017'de erişildi https://www.chp.org.tr/Haberler/4/tumersuriyelilere-vatandaslik-hakki-kaosu-tetikler-46265.aspx

Çelik, N. B. (2015). Türk hukukunda uluslararası koruma başvurusunda bulunan veya uluslararası korumadan yararlanan yabancıların hak ve yükümlülükleri. İnönü Üniversitesi Hukuk Fakültesi Dergisi , 1 (Özel Sayı), 67-148.

Çiçekli, B. (2013).Yabancılar Hukuku. Ankara: Seçkin Yayıncılık.

Demirhan, Y. \& Seyfettin, A.(2015). Türkiye'nin sınır ötesi göç politikaları ve yönetimi. Birey ve Toplum Dergisi, 5(9), 23 - 62.

Dye, T.1995). Understanding Public Policy. New Jersey: Eight Edition, Prentice Hall.

ECPAT (2015). Çocuklara Karşı Ticari Cinsel Sömürü ile Mücadele Küresel İzleme: Türkiye. 7 Ocak 2017'de erişildi http://www.ecpat.net/sites/default/files/A4A_V2_EU_Turkey_FINAL.pdf,(02.01.2017).

Erdoğan, M. \& Ünver, C. (2015). Türk İș Dünyasının Türkiye'deki Suriyeliler Konusundaki Görüş, Beklenti ve Önerileri. TISK Yayını No:353. 
Yalova Sosyal Bilimler Dergisi

Eyestone E, R. (1971). The Threads of Public Policy: A Study in Policy Leadership. USA, BobbsMerrill.

Geçici Koruma Altındaki Yabancılara İlişkin Hizmetlerin Yürütülmesi Başlıklı Başbakanlık Genelgesi. 7 Ocak 2017'de erişildi , https://www.afad.gov.tr/upload/Node/2311/files/20144_sayili_Genelge_-_parafsiz.pdf

Geçici Koruma Yönetmeliği., R.Gazete Tarihi : 22.10.2014, R. Gazete No : 29153. 7 Ocak 2017'de erişildi , http://www.goc.gov.tr/files/files/03052014_6883.pdf

Giritli, S. (5 Temmuz 2016). Suriyelilere vatandaşlığa neden karşı çıkılıyor?. BBC Türkçe, 2 Ocak 2017'de erişildi http://www.bbc.com/turkce/turkiye/2016/07/160704_suriyelilere_vatandaslik

Güleç, C. (2015). Avrupa Birliği'nin göç politikaları ve Türkiye’ye yansımaları. Tesam Akademi Dergisi, 2(2), 81-100.

Güneş, M. (2015). Kamu yönetiminde geçici koruma rejimi ve yakın gelecekte türk kamu güvenliğinde potansiyel bir sorun olarak : Suriyeli mülteciler. XIII. Кати Yönetimi Forumu, 762-786.

Harunoğulları, M. (2016). Suriyeli sığınmacı çocuk işçiler ve sorunları: Kilis örneği. Göç Dergisi, Mayıs, 29-63.

Heywood, A. (2012) .Siyasetin Temel Kavramları. (Çev. Hayrettin Özler), Ankara: Adres Yayınları

Hürriyet, (28 Ocak 2016).2,5 milyona yakın Suriyeli‘ye 8 milyar dolar harcandı. 8 Ocak 2017'de erişildi,http://www.hurriyet.com.tr/2-5-milyona-yakin-suriyeliye-8-milyar-dolar-harcandi40046299 ,

İçduygu, A. (2010).Türkiye'de uluslararası göçün siyasal arka planı: küreselleşen dünyada ulus devleti inşa etmek ve korumak. (ed. B, Push-ch-T.Wilkoszewski), Türkiye'ye Uluslararası Göç. İstanbul: Kitap Yayınevi,

İltica ve Göç Alanındaki Avrupa Birliği Muktesabının Üstlenilmesine İlişkin Türkiye Ulusal Eylem Planı. 10 Ocak 2017'de erişildi http://www.goc.gov.tr/files/files/turkiye_ulusal_eylem_plani(3).pdf

İnsan Hakları İzleme Örgütü (2014). Geleceğimi Hayal Etmeye Çalıştığımda Hiçbir Şey Göremiyorum: Türkiye'deki Suriyeli Mülteci Çocukların Eğitime Erişiminin Önündeki Engeller - Kayıp Nesil Olmalarını Önlemek Raporu, 10 Ocak 2017'de erişildi https://www.hrw.org/sites/default/files/report_pdf/turkey1115tu_web.pdf

Kap D. (2014). Suriyeli mülteciler: Türkiye'nin müstakbel vatandaşlar. Akademik Perspektif, Aralık, 30-35.

Kara, M. \&Dönmez Kara, C.Ö. (2016). Türkiye'de göç yönetișimi:kurumsal yapı ve işbirliği. Journal Of Entrepreneurship And Development, 10(2), 1-25.

Kara, P. \&Korkut, R., (2010). Türkiye'de göç, iltica ve mülteciler. Türk İdare Dergisi , (467), 153162.

Karaca, E. (11 Temmuz 2016). Her mülteciye vatandaşlık için başvuru hakkı tanınmalı. Bi̇A Haber Merkezi, 12 Ocak 2017'de erişildi, http://bianet.org/bianet/insan-haklari/176625-hermulteciye-vatandaslik-icin-basvuru-hakki-taninmali,(02.01.2017).

Kartal, B. \& Başçı, E. (2014).Türkiye'ye yönelik mülteci ve sığınma hareketleri. Celal Bayar Üniversitesi Sosyal Bilimler Dergisi, 12(2), 275-299.

Kaya, İ. \& Yılmaz Eren, E. (2014).Türkiye'deki Suriyelilerin Hukuki Durumu Arada Kalanların Haklarl ve Yükümlülükleri Raporu. İstanbul:SETA.

Klijn H. \& Koppenjan J. (2000).Public management and policy networks: Foundations of a network approach to governance. Public Management. 2: 135-158.

Kolukırık, S. (2014).Uluslararası göç ve türkiye:yerel uygulamalar ve görünümler. Zeitschrift Für Die Welt Der Türken, 6(2), 37-53. 
Yalova Sosyal Bilimler Dergisi

ORSAM (2012). Küresel Göç ve Avrupa Birliği ile Türkiye’nin Göç Politikalarının Gelişimi. Rapor No:22.

ORSAM (2014). Suriye’ye Komşu Ülkelerde Suriyeli Mültecilerin Durumu: Bulgular, Sonuçlar ve Öneriler. Ankara: Ortadoğu Stratejik Araştırmalar Merkezi.

Örselli, E. \& Babahanoğlu, V. (2016). Türkiye'nin göç yönetimi ve göç politikalarının gelişimi: bir kamu politikası analizi. Uluslararası Sosyal Araştırmalar Dergisi The, 9(43), 2063-2072.

Özer, V. (10 Temmuz 2016). Suriyeliye TOKİ. Hürriyet, 12 Ocak 2017'de erişildi http://www.hurriyet.com.tr/suriyeliye-toki-konutlari-40139816

Özer, Y. (2011). Türk kamu yönetiminde yeni bir çalışma alanı olarak uluslararası göç: yasalaşma ve idari yapılanma sürecinin değerlendirilmesi. İ.Ü. Siyasal Bilgiler Fakültesi Dergisi, No:45, Ekim, 73-88.

Öztürk, S. (2015).Suriye'den göçün etkileri. GSA 2015 Global'i Yaşamak Uluslararası Konferansı Bildirisi, İstanbul.

Parlak, B. \& Şahin, A.U. (2015).Türkiye iltica ve göç mevzuatının coğrafi kısıtlama uygulaması yönünden analizi. Tesam Akademi Dergisi, 2(2),65-79.

Pasaport Kanunu. Kanun No: 5682 Kabul Tarihi : 15/7/1950 , R.Gazete Tarihi : 24.7.1950 , R Gazete No: 7564. 12 Ocak 2017'de erişildi http://www.mevzuat.gov.tr/MevzuatMetin/1.3.5682.pdf

Sabatier, P. A. (2007). The Theories of the Policy Process. Colorado:Boulder, WestviewPress.

Şeker, G. \& Sirkeci İ. \&Aslan, Ç. (2014). Yabancılar ve uluslararası koruma kanunu hakkında genel bir değerlendirme. Insan Haklart Yılliğg, 32, 2014, 107-129.

T.C. Aile ve Sosyal Politikalar Bakanlığı (ASPB) Resmi Web Sayfası. Refakatsiz çocuklara yönelik çalışmalar. 2 Ocak 2017'de erişildi,http://cocukhizmetleri.aile.gov.tr/uygulamalar/refakatsizcocuklara-yonelik-calismalar(02.01.2017).

T.C. Başbakanlık Afet ve Acil Durum Yönetimi Başkanlığı (2015). Faaliyet Raporu. 12 Ocak 2017'de erişildi, https://www.afad.gov.tr/upload/Node/3900/xfiles/afad-2015-ifr-web.pdf,

T.C. Başbakanlık Afet ve Acil Durum Yönetimi Başkanlığı. 12 Ocak 2017'de erişildi https://www.afad.gov.tr/tr/2374/Barinma-Merkezlerinde-Son-Durum,

T.C. Dış İşleri Bakanlığı. AB vize muafiyeti sürecine dair mutabakata varıldı. 12 Ocak 2017'de erişildi http://www.mfa.gov.tr/ab-vize-muafiyeti-surecine-dair-mutabakata-varildi.tr.mfa,

T.C. İç İşleri Bakanlığı Göç İdaresi Genel Müdürlüğü, (2017a). 12 Ocak 2017'de erişildi http://www.goc.gov.tr/icerik/hakkimizda_308_309

T.C. İç İşleri Bakanlığı Göç İdaresi Genel Müdürlüğü, (2017c). 12 Ocak 2017'de erişildi http://www.goc.gov.tr/icerik/surekli-kurullar_453_455)

T.C. İç İşleri Bakanlığı Göç İdaresi Genel Müdürlüğü, (2107b). 12 Ocak 2017'de erişildi http://www.goc.gov.tr/icerik/goc-politiklari-kurulu_453_454)

Türk Ceza Kanunu. Kanun No : 5237 , K. Tarihi : 26.9.2004, R.Gazete : Tarih : 12.10.2004 Gazete No : 25611, 12 Ocak 2017'de erişildi, http://www.mevzuat.gov.tr/MevzuatMetin/1.5.5237.pdf

Türkiye 2015 İlerleme Raporu. 14 Ocak 2017'de erişildi http://www.ab.gov.tr/files/ilerlemeRaporlariTR/2014_ilerleme_raporu_tr.pdf.

Türkiye ile Avrupa Birliği Arasında İzinsiz İkamet Eden Kişilerin Geri Kabulüne İlişkin Anlaşma ve Vize Serbestisi Diyaloğu Mutabakat Metni, (Aralık,2015). 2 Ocak 2017'de erişildi http://www.ab.gov.tr/files/stib/TR-ABVizeSerbestisi.pdf

Türkiye'de bulunan 18-45 yaş arası Suriyeli erkekler askere alınsın. Suriye için savaşsın kampanyası, 2 Ocak 2017'de erişildi https://www.change.org/, (02.02.2017).

Türkiye’ye İltica Eden veya Başka Bir Ülkeye İltica Etmek Üzere Türkiye'den İkamet İzni Talep Eden Münferit Yabancılar ile Topluca Sığınma Amacıyla Sınırlarımıza Gelen Yabancılara ve 
Yalova Sosyal Bilimler Dergisi

Olabilecek Nüfus Hareketlerine Uygulanacak Usul ve Esaslar Hakkında Yönetmelik, Kabul Tarihi : 14.09.1994 R.G. Tarihi : 30.11.1994, R.G. No : 22127, 2 Ocak 2017'de erişildi http://www.multeci.org.tr/wp-content/uploads/2016/12/1994-Yonetmeligi.pdf

Uluslararası Af Örgütü (2014). Hayatta Kalma Mücadelesi: Türkiye’ye Suriye’den Gelen Mülteciler Raporu. Amnesty International. 4 Ocak 2017'de erişildi

https://www.amnesty.org/download/.../208000/eur440172014tr.pdf

Uluslararası Af Örgütü (2016). Güvenli Olmayan Sığınak Türkiye'de Siğınmacılar ve Mülteciler Etkili Korumaya Erişemiyor. Amnesty International, 2 Ocak 2017'de erişildi http://amnesty.org.tr/uploads/Docs/2016-turkce67.pdf,

Uluslarası Göç Örgütü (IOM) (2009) Göç Terimleri Sözlügü, Bülent Çiçekli (edt.) http://www.goc.gov.tr/files/files/goc_terimleri_sozlugu(1).pdf

Usta, A. (2013). Kamu politikaları analizine kuramsal bakış. Yasama Dergisi, 24, 78-102.

Yabancilar ve Uluslar aras1 Koruma Kanunu. K. No: 6458, K. Tarihi: 4.4. 2013, R. Gazete Tarihi:11.04.2013, R. Gazete No:28615. 14 Ocak 2017'de erişildi http://www.goc.gov.tr/files/files/goc_kanun.pdf

Yabancıların Çalışma İzinleri Hakkındaki Kanun: Kanun No: 4817 Kabul Tarihi : 27.2.2003, R.Gazete : Tarih : 6.3.2003, R.Gazete No: 2504014 Ocak 2017'de erişildi http://www.mevzuat.gov.tr/MevzuatMetin/1.5.4817.pdf

Yabancıların Türkiye'de İkamet ve Seyahatleri Hakkında Kanun. Kanun No : 5683 Kabul Tarihi : 15.7.1950, R. Gazete Tarih : 24.7.1950, R. Gazete No : 7564. 2 Ocak 2017'de erişildi http://www.mevzuat.gov.tr/MevzuatMetin/1.3.5683.pdf

Yazıcıoğlu, Y. (3 Temmuz 2016). Erdoğan'ın sözleri 'Suriyelilere Vatandaşlık' tartışması başlattı. 14Ocak 2017'de erişildi http://www.amerikaninsesi.com/a/erdoganin-sozleri-suriyelilerevatandaslik-tartismasi-baslatti/3402171.html 